Ethiopian Journal of Environmental Studies \& Management 8(3): 252 - 263, 2015.

ISSN:1998-0507

doi: http://dx.doi.org/10.4314/ejesm.v8i3.2

Submitted: January 09, 2015

Accepted: March 23, 2015

\title{
SPATIAL CHARACTERISTICS: A PLANNERS VIEW OF LOCATIONAL PATTERN AND UNDERLYING FACTORS AMONG SMALL SCALE INDUSTRIES IN ONDO STATE OF NIGERIA
}

FATUSIN, A.F.

Department of Geography and Planning Sciences, Adekunle Ajasin University, P.M.B. 001Akungba Akoko, Ondo State, Nigeria Email: fatusinafolabi@gmail.com

\begin{abstract}
This study investigated the locational pattern and the factors among small scale industries (SSI) in Ondo state of Nigeria. Three hundred and fifty three (353) enterprises were sampled across the nine selected settlements spread across the three senatorial regions of the state. The study made use of quadrant count analysis to investigate the distributional pattern, $t$ test to compare the distributional pattern among formal and informal small scale industries and factor analysis to isolate major locational factors. The study established that there existed significant difference in the distributional patterns of small scale enterprises in the sampled settlements. For example, while $40 \%$ of the sampled industries were located in Ondo Central, 31\% were in Ondo South, while 28\% were in Ondo North. Moreover, $82 \%$ of the industries were concentrated in the major urban areas of Akure, Ikare and Okitipupa, with the minor urban areas of Ode Aye, Ugbe and Obaile accounted for 11.3\%, while the villages of Iboropa, Aponmu and Ikoya were almost insignificant with 5.9\%. The study further established that the distributional pattern of SSI in Ondo North was regular (Iboropa V.M.R 0.15, Ikare, V.M.R 0.41, and Ugbe V.M.R 0.32), in Ondo Central, the SSI did not show regular pattern, here while some were regular (Obaile V.M.R 0.32) Some exhibited random pattern (Aponmu V.M.R 0.91) and Akure clearly showed clustered pattern (V.M.R 1.30). In Ondo South, the tendency was regular distribution, Ikoya and Ode Aye being Regular (V.M.R 0.27, V.M.R 0.81) while Okitipupa was clustered (V.M.R 1.70). An application of Anova revealed that there is no significant uniformity in V.M.R values of all the 9 settlements, since the calculated $F$ ratio (1.0494) was less than the tabulated $F$ ratio (5.14). Yet an application of factor analysis revealed that access to labour, power and proprietors personal preferences $(0.77,0.72$, and, 0.57 loadings) were major factors of location.
\end{abstract}

Key Words: Small scale industries, Distributional pattern, Locational factors, Agglomeration, Proprietors

\section{Introduction}

Various studies involving economic development planners, epidemiologists, and social development planners are adopting spatial analysis in their various disciplines to investigate distributional patterns of occurrences in order to be able to intervene effectively in their areas of interest, especially in problems which have spatial connotation. This study investigated the locational pattern and factors of small scale industries in Ondo state, with an assumption that intervention to improve this industrial sub sector will be better served if these tendencies are better understood. 
One of the often touted solutions to the problems impeding development in the third world countries is the emphasis on small scale industrial enterprises (SSI). The intention behind the encouragement of the SSI, according to Endashaw (2009) lies in the development of a diversified economy that could propel the achievement of stable and sustainable societies, since the agricultural sector, the main economic activity in Sub-Saharan African countries cannot provide enough employment and income to the growing population.

This is because small scale industries, as acknowledged by the World Bank (2004), attract indigenous labour, account for a substantial part of the total manufacturing value added, employ significant number of people in Africa and Latin America (Dutta, 2005) and offer strong grounds for linkage creation between rural and urban population (Kappel, 2004, Sanni 2009).

An analysis of spatial pattern of small scale industries in the state not only reveal locational pattern of distribution of plants, it may also reveal the patterns of industrial pollution and industrial wastes generation, trip generation, traffic pattern, pattern of disease infection and spatial distribution of poverty within the city structure, areas that are crucial to development of African economies

The study is focused on enterprises considered to be small-scale industries, both formal and informal. Small-scale industries are limited to enterprises that actually take part in production and not service-based enterprises. That is why for example, a soapmaking SSI was considered, while mechanic workshop, or shoe repair workshop was considered outside the scope, since they only render services. The study involves an examination of the classes of SSI, the locational tendency and trends.

For the purpose of this study, formal small scale industry is defined as a productive enterprise adopting automated or labour intensive mode of production, which employs maximum of 30 workers and whose capital outlay is not more than N 3 million (BOI Report, 2005). This definition has been arrived at for the following reasons: Bank of Industry Report of 2003, being the latest classification of industries in Nigeria. Moreover the use of other classification other than that of Nigeria may not be applicable, since different countries have their own basis of classification.

Ondo State like every state in Nigeria suffers from inequality in the location of small scale industries. Some major parts of the cities and regions seem to be the hub of new investments in SSI development; others attract few or no new investment at all. Yet the industrial policy of the State has among other objectives balanced industrial development and a deliberate effort to channel new SSI entrants into areas with low propensity to attract investment since the spatial distribution of industries within the cities also reflects the spatial distribution of poverty (Locker, 2009).

Industrial location analysis may be defined as the study of the spatial arrangement of industrial activity (Smith, 1981). Abler et al. (1972) observed, "What we call spatial processes are mechanisms which produce spatial structures of distribution". Spatial processes can therefore give some views as to the factors that bring about spatial pattern of industries located for particular reasons.

From classical industrial location theorists contemporary contributors to locational analysis included Coss et al. (2001), Holl, (2004), Mckee (2007) and Verme (2010). These contributors have been able to establish that the spread of industry is more of a consequence of changes within each country i.e. policy reforms enabling specialization, comparative advantage and government intervention targeted at attracting investment, rather than transportation cost. Indeed these factors of location were prominent in the works of Cieslik (2005) and Siebert (2006) who agree that tendency to locate with other competitors is equally importantthe world 
has passed that stage of considering transport cost as the most dominant factor of location. He draws his findings from the fallout of globalisation and the attendant economic implication especially the phenomenal growth of manufacturing in South East Asia.

Head et al. (1999) use a discrete choice model to examine the locations of new Japanese-owned establishments across US States. Among the factors, they find influence location the most important factor among number of US-owned establishments in the same industry, and the number of Japanese-owned establishments both within and outside the country. In a paper that looks at the effects of policy instruments on the location choices of foreign multinationals within France, Crozet et al. (2003), found little evidence of an impact of either European regional policy or French national policy on location decisions. The authors do find evidence of agglomeration effects that differ by industry and the nationality of the SSI. Guimaraes et al. (2000) investigate the impact of withinindustry spillovers on the plant locations chosen by foreign multinational companies in Portugal. They use small regional units, in an attempt to identify the impact of very local spillovers. They too find significant agglomeration effects.

Devereux and Griffith (1998) look at the effect of profits taxes on the location of US firms. They find that corporate income tax have an effect on a firm's decision of which country within Europe to locate in, but not on the choice between exporting, locating in Europe or not serving the foreign market at all. Agglomeration effects are also found to play a significant role. Head et al. (2000) investigated many Japanese owned firms and finds that Japanese firms tend to locate in countries that have already had significant inward investment from Japan.

In the developing countries studies have concentrated on economic benefits of small scale industries with little emphasis on their spatial characteristics. This assertion was supported by Oyelakin-Oyelarin (1997) in his study of SSI industrial clusters of Nnewi and Akinbinu (2001) who studied the informal SSI cluster in auto mechanic village in Ibadan. Fatusin (2010) in his study of locational pattern of small scale industries in Akoko region discovered an uncontrolled and unorganised growth of small scale industries, which was attributable to physical planning failures in the cities constituting the region.

\section{Study Area}

Ondo State lies between latitudes $5^{\circ} 45^{\prime}$ and $7^{\circ} 52^{\prime} \mathrm{N}$ and longitudes $4^{\circ} 20^{\prime}$ and $6^{\circ}$ $05^{\prime} \mathrm{E}$. Its land area is about 15,500 square kilometres. Ondo State is bounded on the east by Edo and Delta states, on the west by Ogun and Osun States, on the north by Ekiti and Kogi States and to the south by the Bight of Benin and the Atlantic Ocean Ondo State took off formally on 1st April 1976, consisting of the nine administrative divisions of the former Western State (Ondo Ministry of Information and Culture, 1979). The state covered the total area. These nine divisions then were Akoko, Akure, Ekiti Central, Ekiti North. Ekiti South. Ekiti West, Okitipupa, Ondo and Owo. Akure town-ship was retained as the state headquarters. However, on 1st October 1996. Ekiti State comprising Ekiti Central, Ekiti North, Ekiti South and Ekiti West Divisions was carved out of Ondo State. Hence, the present Ondo State is made up of Akoko, Akure, Okitipupa, Ondo and Owo divisions. Akure remains the State capital (figure 1.) The state has a long history of craft industries. Owo for example was noted for its pottery and beads, Ondo for weaving and metal smelting, Akure was a centre of bronze making, while Okitipupa was noted for production of indigenous soap as well as water based SSI such as fish and shrimp processing and gin making. 


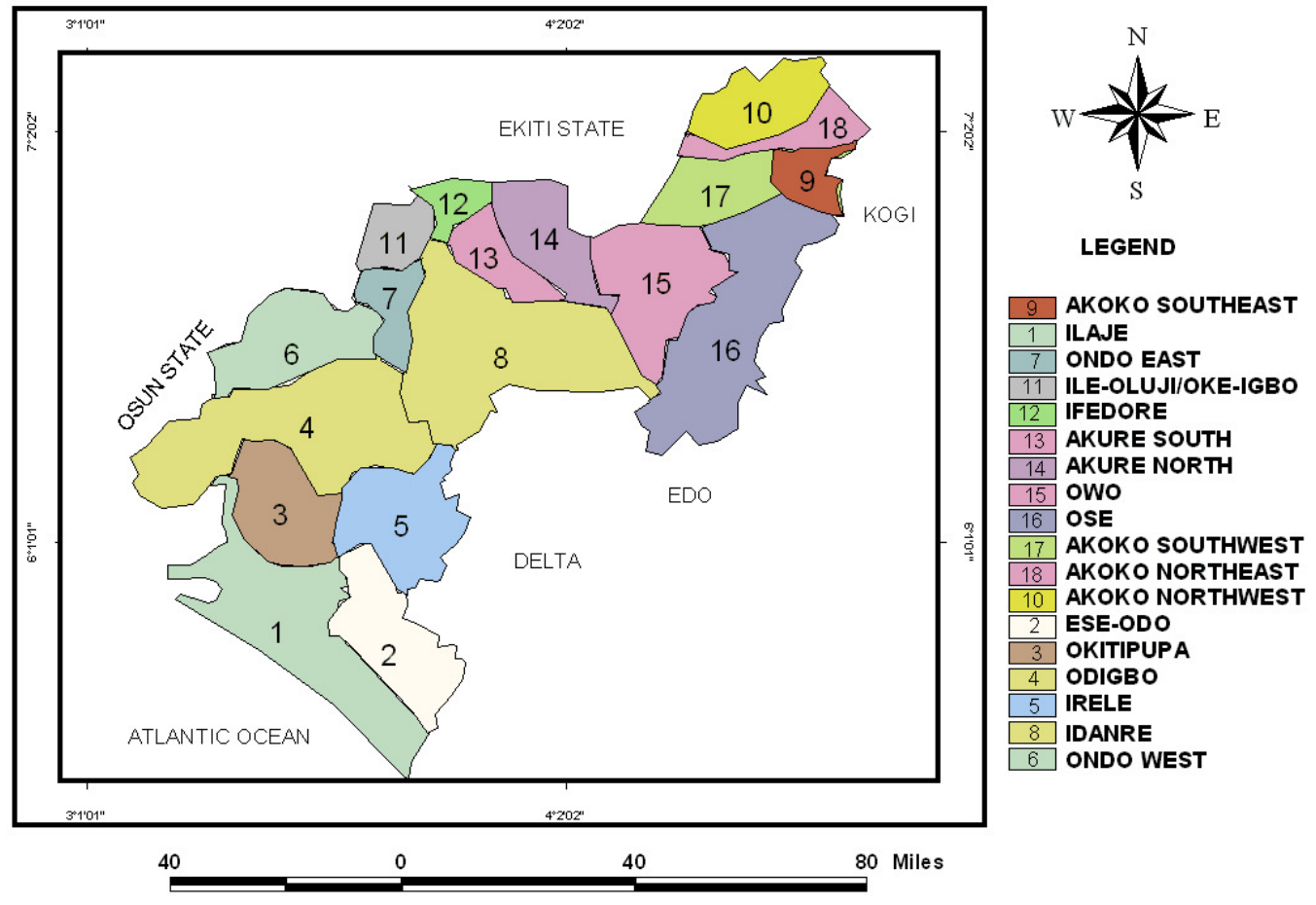

Source: Ondo State Annual Report (2009)

Figure 1: Local Government Areas of Ondo State

\section{Materials and Methods}

In order to make the study representative of the entire state, three (3) major towns Akure, Ikare and Okitipupa, three (3) minor towns Ugbe, Obaile and Odeaye, three (3) major villages; Iboropa,Aponmu and Ikoya were investigated. In order to select the settlements, towns and villages in the three regions of the state were classified into three (3) groups depending on their population size.

A-Those with population of over 80,000 people (major towns)

B-Those with population of between 70,999 and 20,000 people (minor towns)

C-Those with less than 20,000 people (village)

One settlement was picked from each of the above groups in each region using simple random sampling technique. The sample frame covered all the SSI (formal and informal) in the nine settlements selected. There were 1411 in the study area.The sample size of the SSI was 353 . This constitutes $25 \%$ of the entire sample frame (1411). Questionnaires were administered on proprietors of small scale industries. Small scale industries in each town were first identified and numbered during reconnaissance survey. Twenty-five percent $(25 \%)$ of the industry in each of the nine settlements were sampled for interview. Data were analyzed by using Quadrant Count Analysis and Factor Analysis where appropriate.

\section{Results and Discussion}

Analyses of the locational patterns of the sampled small scale enterprises were done under three headlines - interregional, intercity and intra city.

The study found out that majority of the small scale industries in Ondo State were located in Ondo Central. The region accounted for $40 \%$ (141) of all the industries sampled as shown in Table 5. This was followed by Ondo South with 31\% (110) of the total number of industries sampled. The least number of industries were concentrated in Ondo North with $28.9 \%$ (102) of the industries. 
Table 1: Locational Distribution of Small Scale in the Senatorial Regions

\begin{tabular}{llll}
\hline S/N & Region & No. of sampled industries & $\%$ \\
\hline 1 & Ondo central & 141 & 40 \\
2 & Ondo North & 102 & 28.9 \\
3 & Ondo South & 110 & 31 \\
\hline
\end{tabular}

The above result shows that, of the three regions, Ondo Central is the most urbanized with the highest population (Table 1). Industries tend to concentrate where markets are easily accessible for their products.

Inter Settlements' Variation in Small Scale Industrial Concentration in the Study Area

Small scale industrial concentration was investigated among the nine selected settlements - Akure, Ikare, Okitipupa, Ugbe, Obaile, Ode-Aye, Iboropa, Aponmu and Ikoya. The study found out that Akure accounted for $35.6 \%(126)$ of all the industries sampled. This was followed by Ikare with 24\%(85) of the industries, Okitipupa with 23\% (81), Ode Aye with 5\% (18), Ugbe with $3.4 \%$ (12), Ikoya with $3.1 \%(11)$, Oba-Ile with $2.8 \%(10)$. Iboropa and Aponmu both had 5 firms each or $1.4 \%$ of all the sampled enterprises.

The locational patterns of the industries were further analysed among the three classes of settlements in which the nine settlements belong - major urban area, minor urban area and major villages.

Table 2: Locational Concentration of Small Scale Industries Relative to Degree of Urbanization

\begin{tabular}{llll}
\hline Classes of settlement & $\begin{array}{l}\text { Settlements in each } \\
\text { category }\end{array}$ & $\begin{array}{l}\text { No. of } \\
\text { industries }\end{array}$ & $\begin{array}{l}\text { \% of } \\
\text { industries }\end{array}$ \\
\hline Major urban area & Akure & 126 & \\
& Okitipupa & 81 & \\
& Ikare & 85 & 82 \\
Minor urban area & Total & 291 & \\
& Ode Aye & 18 & \\
& Ugbe & 12 & 11.3 \\
& Obaile & 10 & \\
Villages & Total & 40 & \\
& Iboropa & 5 & 6 \\
\hline
\end{tabular}

From the Table 2 it is quite evident that industries were urban biased in the state. For example, out of the 353 industries sampled, $82 \%$ were located in the major urban areas of Akure, Ikare and Okitipupa, while only $11.3 \%$ were located in the minor towns of Ode Aye, Ugbe and Obaile. The villages had just 21 industries which accounted for only $6 \%$ of all the 353 industries sampled. This discovery agrees with Luches (1948) view that many industries were mostly attracted by market factors. Market factor on the other hand is determined by population concentration.

\section{Intra Urban Variation in Small Scale Industrial Concentration}

The distributional pattern of small scale industries varied within the town structure. While small scale industries in some settlements were randomly distributed, some were clustered and yet, some were regularly distributed. The distributional patterns of formal and informal 
small scale industries were subjected to Quadrant count analysis using Poisson distribution formula separately and collectively. The nine settlements were first gridded into quadrants (Figures 2 -10). The variance mean ratios (V.M.R) were calculated for all the settlements selected as shown in Table 3.

Table 3: Summary of Distributional Pattern of Industries in the Study Area

\begin{tabular}{llllll}
\hline S/no & Settlement & Industries & Quadrants & V.M.R & Remark \\
\hline & Akure & 126 & 48 & 1.30 & Clustered \\
Aponmu & 05 & 42 & 0.91 & Random \\
Iboropa & 05 & 40 & 0.15 & Regular \\
& Ikare & 81 & 36 & 0.41 & Regular \\
& Ikoya & 11 & 24 & 0.27 & Regular \\
& Oba ile & 10 & 25 & 0.32 & Regular \\
& Ode- aye & 18 & 36 & 0.81 & Regular \\
Okitipupa & 61 & 36 & 1.70 & Clustered \\
& Ugbe & 12 & 25 & 0.24 & Regular \\
\hline
\end{tabular}

The Table 3 showed the variance mean ratio values for all categories of small scale Industrial enterprises in the 9 settlements selected for investigation with Akure, and Okitipupa having V.M.R. 1.30 and V.M.R. 1.70 which were clearly clustered, while Aponmu was tending toward random (V.M.R 0.91). Small scale industries in other settlements had regular distribution patterns - Iboropa (V.M.R 0.15; Ikare V.M.R 0.41) Ikoya V.M.R 0.27; Oba Ile (V.M.R 0.32), Ode Aye (V.M.R 0:81) and Ugbe (V.M.R 0:24)

In order to gain more insight into the research, the V.M.R values of Small Scale Industries were analysed on the basis of region to show further comparison. The study revealed that the distributional pattern in Ondo North was clearly regular with Iboropa, Ikare and Ugbe being V.M.R 0.15, V.M.R 0.41 and V.M.R 0.24 (See Table 1.4). In Ondo Central the pattern was very divergent, with Akure being clustered (V.M.R 1.30), Aponmu being random, (V.M.R $0.91)$ and Obaile being regular (0.32).

In Ondo South, the distributional pattern tended toward regular, with Ikoya and Ode-Aye being regular (V.M.R 0.27 and V.M.R 0.81), while Okitipupa was clustered with V.M.R 1.70 respectively.

Table 4: Variance Mean Ratio of Small Scale Industries across Regions

\begin{tabular}{llllll}
\hline \multicolumn{2}{l}{ Ondo North } & & & & \\
\hline S/no & Settlement & Industries & Quadrants & V.M.R & Remark \\
\hline 1. & Iboropa & 05 & 40 & 0.15 & Regular \\
2. & Ikare & 81 & 36 & 0.41 & Regular \\
3. & Ugbe & 12 & 25 & 0.24 & Regular \\
\multicolumn{2}{l}{ Ondo Central } & & & & \\
4. & Akure & 126 & 48 & 1.30 & Clustered \\
$5 . \quad$ Aponmu & 05 & 42 & 0.91 & Random \\
$6 . \quad$ & Oba-Ile & 10 & 25 & 0.32 & Regular \\
Ondo South & & & & \\
$7 . \quad$ Ikoya & 11 & 24 & 0.27 & Regular \\
8. & Ode-Aye & 18 & 36 & 0.81 & Regular \\
9. & Okitipupa & 61 & 36 & 1.70 & Clustered \\
\hline
\end{tabular}

The pattern of distribution of small scale industries was also investigated along major towns, minor towns and major villages. Thus, while the pattern was clearly regular in minor 
towns of Oba-Ile, Ode Aye and Ugbe as shown in Table 5 (V.M.R 0.32, V.M.R 0.81 and V.M.R 0.24), it tended towards clustered in major towns of Akure and Okitipupa (V.M.R 1.30 and V.M.R 0.41) but regular in Ikare (V.M.R 0.41).On the other hand, the distributional pattern in major villages of Iboropa and Ikoya were regular (V.M.R 0.15 and V.M.R 0.27) while Aponmu was random (V.M.R 0.91)

Table 5: Distributional Pattern of Small Scale Industries by Size of Settlements

\begin{tabular}{|c|c|c|c|c|c|}
\hline \multicolumn{6}{|c|}{ Major Towns } \\
\hline S/no & Settlement & Industries & Quadrants & V.M.R & Remark \\
\hline 1. & Akure & 126 & 48 & 1.30 & Clustered \\
\hline 2. & Ikare & 81 & 36 & 0.41 & Regular \\
\hline 3. & Okitipupa & 61 & 36 & 1.70 & Clustered \\
\hline \multicolumn{6}{|c|}{ Minor Towns } \\
\hline 4. & Oba-Ile & 10 & 25 & 0.32 & Regular \\
\hline 5. & Ode-Aye & 18 & 36 & 0.81 & Regular \\
\hline 6. & Ugbe & 12 & 25 & 0.24 & Regular \\
\hline \multicolumn{6}{|c|}{ Major Villages } \\
\hline 7. & Aponmu & 05 & 42 & 0.91 & Random \\
\hline 8. & Iboropa & 05 & 40 & 0.15 & Regular \\
\hline 9. & Ikoya & 11 & 24 & 0.27 & Regular \\
\hline
\end{tabular}

The significance level of clustering of industries in the study area was tested using ANOVA as shown in Table 6.

Table 6: Test of Significance on level of Clustering

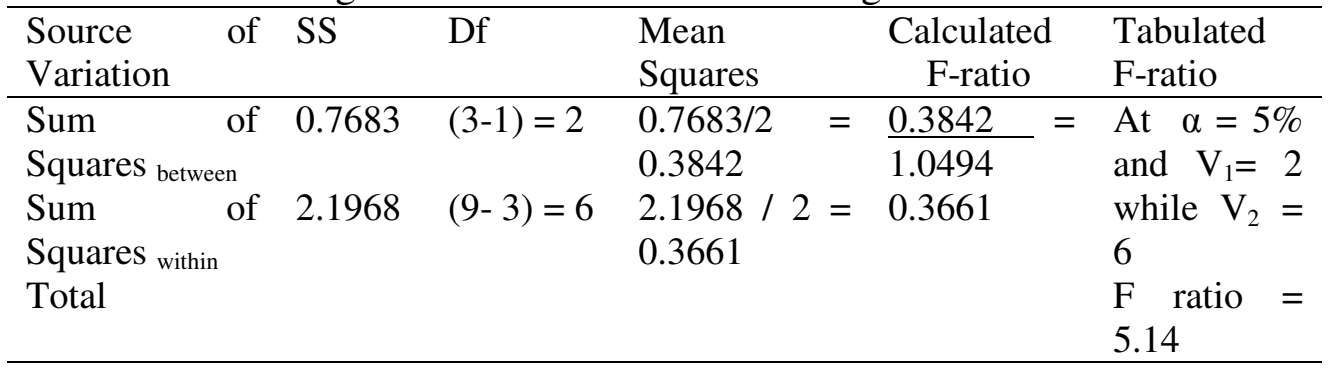

Since the calculated F-ratio (1.0494) was lesser than the tabulated F-ratio (5.14) it can be inferred that there was no significant uniformity in the Variance mean ratio values of industries across the regions of the study area. Therefore, the distributional patterns of industries in the settlement did not show the same tendency. 
Location of Small Scale Industries in the Nine Selected Settlements

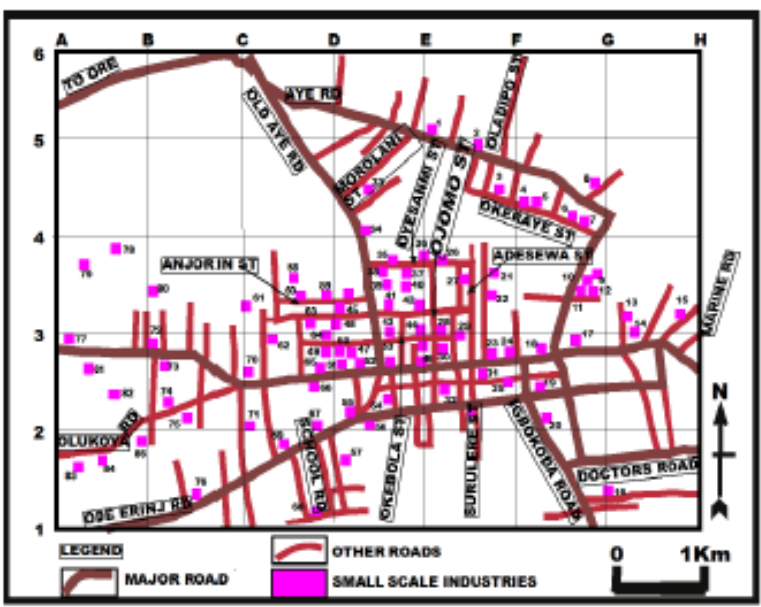

Map: 3. Quadrant Count Analysis of Small Scale Industries in Okitipupa.

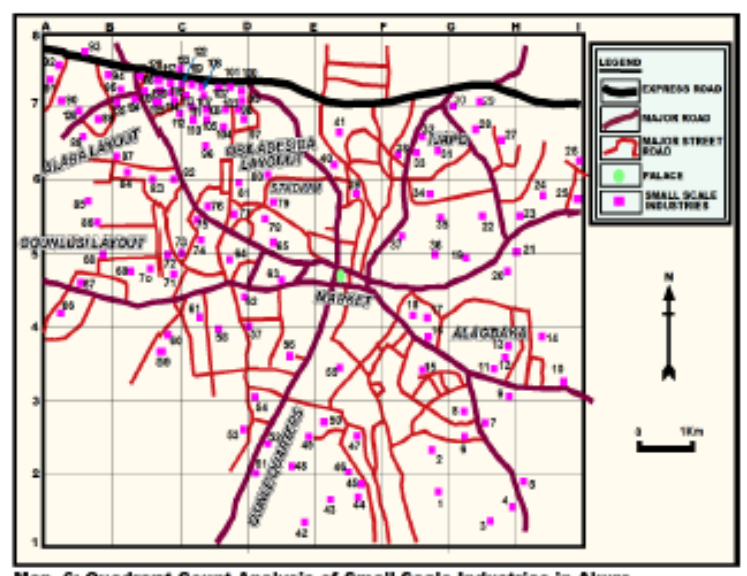

Map. 6: Quadrant Count Analysis of Small Scale Industries in Akure.

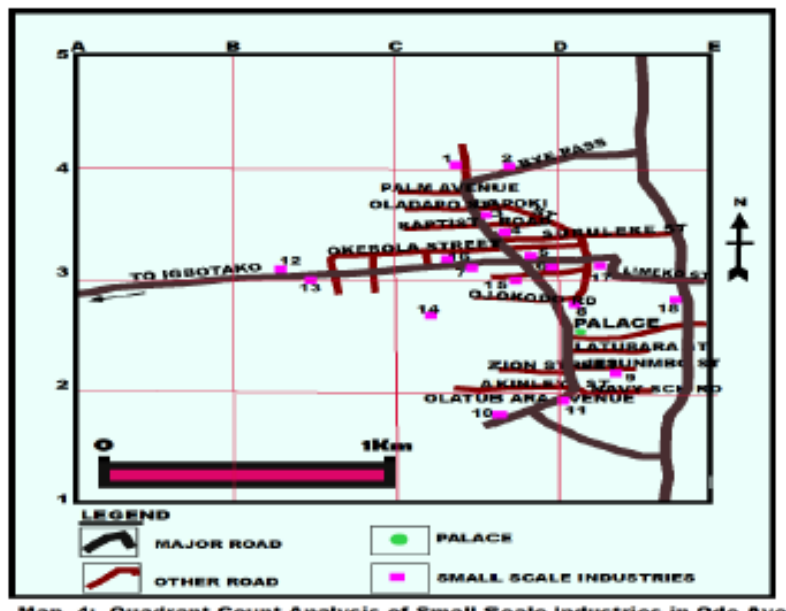

Map. 4: Quadrent ceunt Anatysis of small seate Intustries in ods-Aye

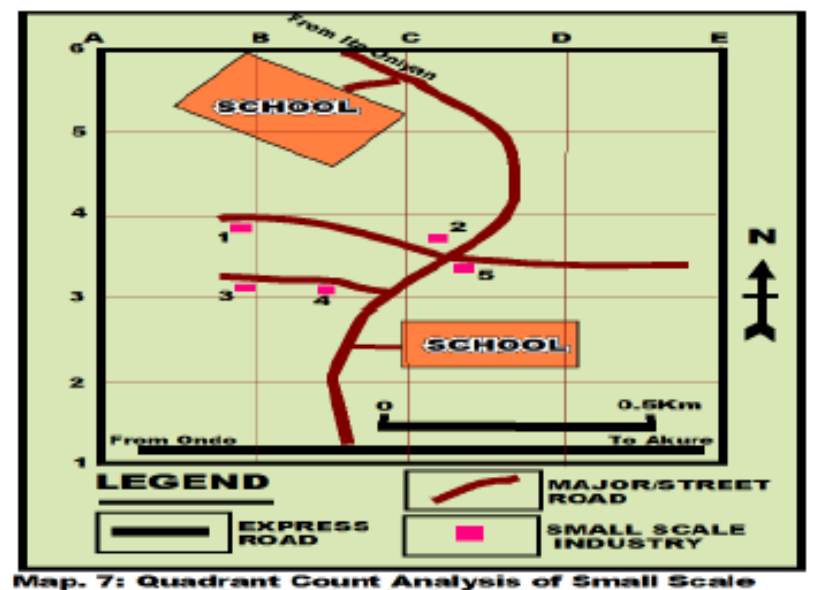

Map. 7 : Quadrant Coum Analysis of Small scalo
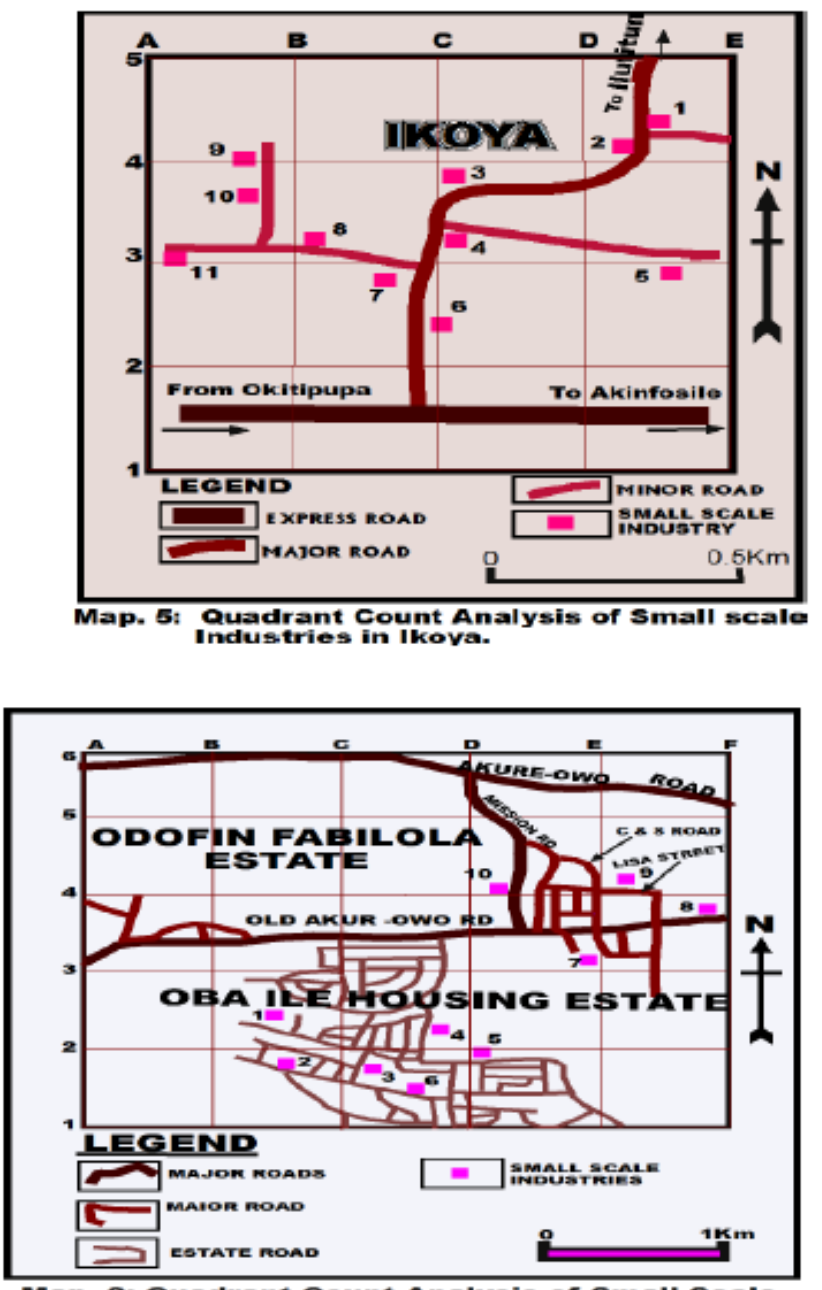

Industries in olysis of 

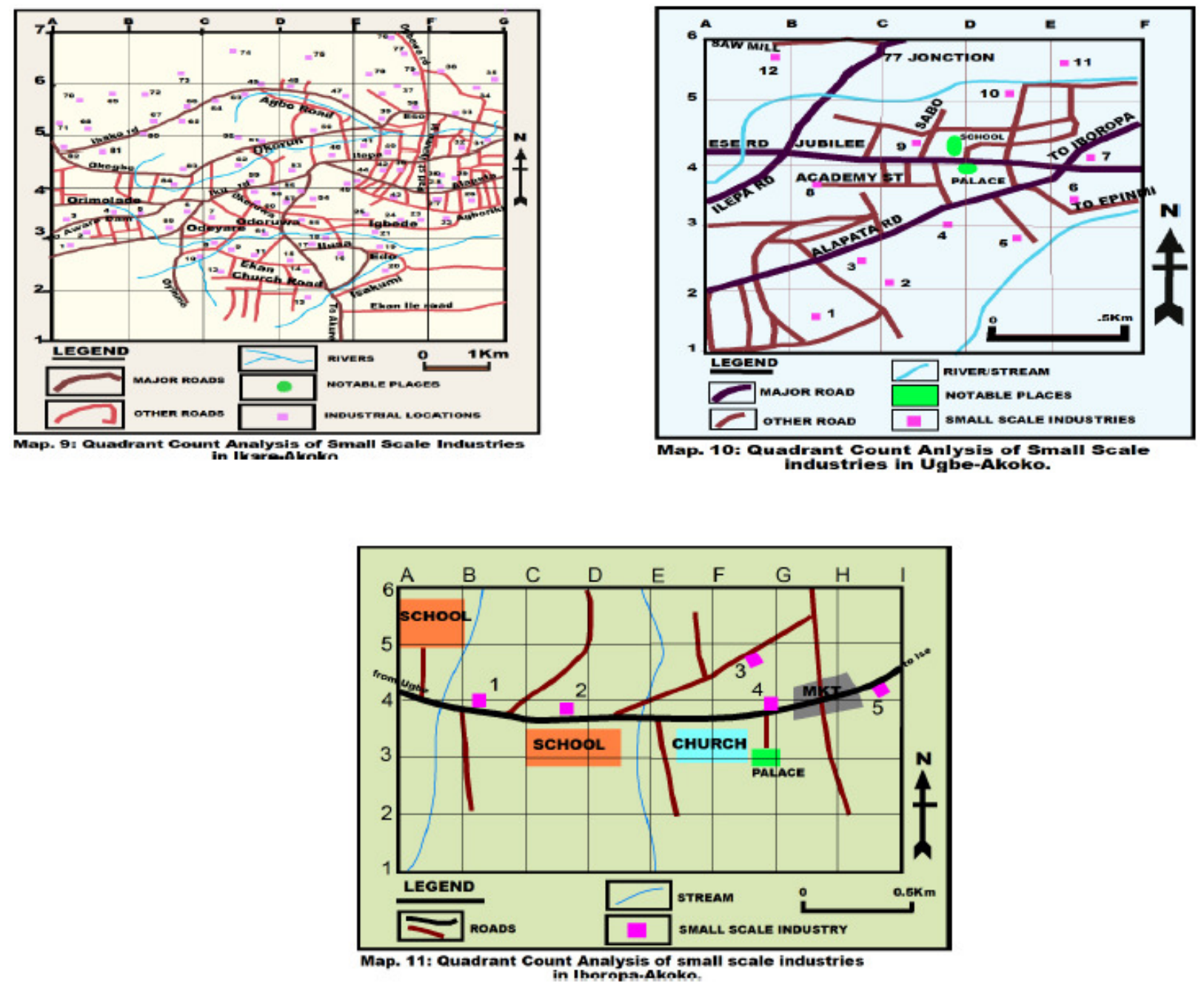

\section{Location Factor Analysis}

Analysis of the 353 questionnaires administered on proprietors revealed some locational factors. These locational factors included nearness to raw materials, nearness to power, nearness to other market, access to land, accessibility and nearness to labour. These factors of location were prominent in the works of Chan (2005), Cieslik (2005) and Siebert (2006) who agree that the environment where production takes place determine the extent of these factors. This study found out that many industries in the study area deliberately located where electricity was available to power their plants. Many such as pure water industries preferred to locate where they could readily get market because of the burden of transporting finished products to markets, yet some, such as constructional blocks making enterprises preferred to locate where they could get their raw materials such as sand and most especially water. That was why out of about 25 blocks making industries sampled $72 \%$ (18) of them locate their plants within 50metres to streams, and rivers or water logged landscape. Some small scale industries in the study area also located their plants in order to enjoy easy accessibility, some locate where they could get land or shops, and others sited their plants somewhere because of psychological attachment to a particular site or town.

In order to reduce some fifteen identifiable variables and determine the most important contributors to location decisions of entrepreneurs, factor analysis 
was applied. Extraction method using principal component analysis was applied.
The total variance was derived and seven factors were discerned (Table 7).

Table 7: Total Variance Explained

\begin{tabular}{|c|c|c|c|c|c|c|c|c|c|}
\hline \multirow[t]{2}{*}{ Component } & \multicolumn{3}{|c|}{ Initial Eigen values } & \multicolumn{3}{|c|}{$\begin{array}{l}\text { Extraction sums of squared } \\
\text { loadings }\end{array}$} & \multirow{2}{*}{$\begin{array}{l}\text { Rotation } \\
\text { loadings }\end{array}$} & \multirow{2}{*}{$\begin{array}{l}\text { sums of } \\
\%\end{array}$} & \multirow{2}{*}{$\begin{array}{l}\text { squared } \\
\text { variance } \\
\text { cum. \% }\end{array}$} \\
\hline & Total & $\%$ & $\begin{array}{l}\text { variance } \\
\text { cum. } \%\end{array}$ & Total & $\%$ & $\begin{array}{l}\text { variance } \\
\text { cum. } \%\end{array}$ & & & \\
\hline $\begin{array}{l}\text { 1.Nearness to raw } \\
\text { materials }\end{array}$ & 1.957 & 27.960 & 27.960 & 1.957 & 27.960 & 27.960 & 1.719 & 24.558 & 24.558 \\
\hline 2. Nearness to power & 1.149 & 16.414 & 44.374 & 1.149 & 16.414 & 44.374 & 1.253 & 17.905 & 42.462 \\
\hline 3. Nearness to market & 1.074 & 15.349 & 59.723 & 1.074 & 15.349 & 59.723 & 1.137 & 16.243 & 58.706 \\
\hline 4. Access to land & 1.056 & 15.091 & 74.814 & 1.056 & 15.091 & 74.814 & 1.128 & 16.108 & 74.814 \\
\hline 5. Access to labour & .825 & 11.785 & 86.599 & & & & & & \\
\hline 6. Accessibility & .542 & 7.743 & 94.342 & & & & & & \\
\hline 7. Personal factors & .396 & 5.658 & 100.000 & & & & & & \\
\hline
\end{tabular}

Table 8: Component Matrix

\begin{tabular}{llllll}
\hline $\begin{array}{l}\text { Locational } \\
\text { factors }\end{array}$ & & 1 & \multicolumn{2}{c}{ Component } & \multicolumn{1}{c}{4} \\
\hline Power & .701 & & \multicolumn{2}{c}{3} & .157 \\
Labour & .684 & .222 & -.241 & .388 \\
Accessibility & .488 & $5.378 \mathrm{E}-02$ & $8.175 \mathrm{E}-02$ & .392 \\
Market & -.465 & -.385 & .387 & .349 \\
Political & .521 & .730 & $-5.194 \mathrm{E}-02$ & $-9.225 \mathrm{E}-02$ \\
Raw material & .418 & .606 & $9.299 \mathrm{E}-02$ & -.334 \\
Land & .311 & $-9.999 \mathrm{E}-02$ & -.752 & -.697 \\
\hline
\end{tabular}

Table 9: Rotated Component Matrix

\begin{tabular}{lllll}
\hline & \multicolumn{1}{c}{1} & & \multicolumn{1}{c}{ Component } & \multicolumn{1}{c}{4} \\
\hline Labour & .770 & -.163 & & \multicolumn{1}{c}{3} \\
Power & .727 & $1.267 \mathrm{E}-02$ & $-4.837 \mathrm{E}-02$ & $-7.747 \mathrm{E}-02$ \\
Personal preferences & .575 & .319 & $.842 \mathrm{E}-02$ & .306 \\
Market & $-3.928 \mathrm{E}-02$ & .887 & .465 & $9.150 \mathrm{E}-02$ \\
Accessibility & .485 & -.545 & -.161 & -.245 \\
Land & $1.847 \mathrm{E}-02$ & -.149 & -.105 & -.384 \\
Raw material & .174 & -.141 & .938 & $-4.594 \mathrm{E}-02$ \\
\hline
\end{tabular}

The component matrix tables were derived as shown in Tables 7 and 8 . Out of these, access to labour, access to power and personal preferences, were the most important factors in the location of small scale enterprises in Ondo State. These factors have the most important eigenvalues of $0.770,0.727$ and 0.575 and therefore formed the major factors that determine location as shown in table 9. Other factors were relatively insignificant.
This result however contrast with the work of Badri (2007) who studied dimensions to industrial location factors in United Arab Emirate and found out that transportation, access to good site and access to raw materials were the major locational factors (eigenvalues $0.70,0.61$ and 0.57 ). This is hardly surprising, environment determines enterpreneural behaviours, and decisions are reflected in space in form of industrial location. 


\section{Summary and Conclusion}

The spatial distribution of small scale industries in Ondo State showed variations inter-regional, inter settlement and intra settlement. Out of the 353 enterprises sampled, $40 \%$ (141) were located in Ondo Central 31\% (110) in Ondo South 28.9\% (102) in Ondo North. From this analysis, one can inferre that Ondo Central region was the most industrialized region in Ondo State. The nine settlements were further divided into major urban areas (Akure, Okitipupa and Ikare) minor urban areas (Ode Aye, Ugbe, Obaile) and villages (Iboropa, Aponmu and Ikoya). It was discovered that most of the industries were concentrated in the major urban area with $82 \%$ (291) of all the sampled enterprises. This is followed by the enterprises in the minor urban areas which accounted for $11.3 \%$ (40) and the least being the villages where we had $6 \%$ (21) of the 353 enterprises sampled.

The Variance mean ratio (V.M.R) of all classes of industries were investigated regionally to discover the distributional pattern and see whether there was any similarity or differences. The study discovered that SSIs, in Ondo North were perfectly regular (Iboropa V.M.R 0.15, Ikare V.M.R 0.41, Ugbe V.M.R 0.32). In Ondo Central, SSIs did not show the same tendency, some being regular (Obaile V.M.R 0.32) some being random (Aponmu V.M.R 0.91) and some being clustered (Akure V.M.R 1.30). For the major towns of Akure and Okitipupa the V.M.R values showed tendency toward cluster distribution (V.M.R 1.30 and V.M.R 1.70) with an exception if Ikare which was regular (V.M.R 0.41). In Ondo South the tendency is regular distribution, Ikoya and Ode Aye being Regular (V.M.R 0.27, V.M.R 0.81) while Okitipupa was Clustered (V.M.R 1.70) .The Variance mean ratio in minor towns of Obaile, Ode Aye and Ugbe were all regular (V.M.R
0.32, V.M.R 0.81, and V.M.R 0.24); while being more of regular distribution in major villages of Iboropa and Ikoya (V.M.R 0.15 and V.M.R 0.27) with an exception in Aponmu which was random (V.M.R 0.91). An application of Anova revealed that there was no significant uniformity in the Variance mean ratio of the settlements since the calculated $\mathrm{F}$ ratio (1.0494) is lesser than the tabulated $F$ ratio (5.14).

The study also discovered through application of factor analysis that factors such as, access to labour, access to power, and individual entrepreneurs personal biases were the major factors influencing location decisions of proprietors. These factors accounted for $0.770,0.727$ and 0.575 of the variance.

\section{References}

Abler, R., Adams, J.S. and Gould, P. (1972). Spatial Organisations. The Geographers View of the world London.ed 3.pp25-28.

Akinbinu, A. (2001). Small and Medium Scale Industries in Nigeria. NISER Monograph, Ibadan.

Cieslik, A. (2005). Location of foreign firms and national border effects: the case of Poland. Tijdschrift voor Economische en Sociale Geografie, 96(3): 287-297.

Coss, A., Raff, H. and Ryan, M. (2001). "Intra and Inter Industry Linkages in Foreign Direct Investment:Evidence from Japanese Investment in Europe, University of Kiel.

Crozet, R., Mayer, T. and Mucchielli, A. (2003). How Do Firms Agglomerate? A Study of FDI in France. CEP Discussion Paper 3873

Devereux, M.P. and Griffith, R. (1998). "Taxes and the Location of Production: Evidence from a panel of US Multinationals" Journal of Public Economics 68: 335 - 367. 
Dutta, S. (2005). Urbanisation and Development of Rural Small Scale Enterprises, Studying the Landscape with Focus on West Bengal. http://www.epw.org

Endashaw, T. (2010). Rural Small Scale Industries and District. $A$ Phd Dissertation submitted to the Department of urban and Regional Planning, Kwame Nkrumah University of Science and Technology Kumasi, Ghana.

Fatusin, A. (2008). Regional impacts of Small Scale Industrial Enterprises in Akoko Region of Ondo State, Unpublished M.Phil Dissertation Submitted to the Dept of Urban and Regional planning. O.A.U, Ile - Ife.

Guimaraes, P., Figueredo, O. and Woodward, D. (2000). "Agglomeration and the Location of Foreign Direct Investment in Portugal", Journal of Urban Economics 47: 115 - 135.

Head, K., Ries, J. and Swenson, D. (1995). "Agglomeration Benefits and Location Choice: Evidence from Japanese Manufacturing Investments in the Unites States", Journal of International Economics, 38: 223247.

Holmes, T. J. (1998). “The Effect of State Policies on the Location of Manufacturing: Evidence from State Borders", Journal of Political Economy 106: 667 - 705.

Holl, A. (2004). "Production Subcontracting and Location: Panel
Data Evidence from Spanish Manufacturing Firms. Journal of Regional Studies. University of Sheffield.

Kappel, R. (2004): “The Missing Links Uganda's Economic Reforms and Pro - poor Growth",

Report Commissioned by Deutsche Gessellschaft fur Technische Zusammenarbeit (GTZ), Eschborn, February 2004

Krugman, P. (1991). "Increasing Returns and Economic Geography" Journal of Political Economy 99(3): 483 499.

Little, D. (1998). "Small manufacturing enterprises in Developing countries". The World Bank Economic Review, 2: 203-235.

Ondo State (2000). "A Directory of Industrial Establishment, Ministry of Finance and Economic Development (Statistics Division), Akure

Sunni, O. (2009). Problem of Establishing small Business Enterprises in Nigeria, A case study of Alalteef Nig. 1td. A n M.sc Thesis submitted to the Vaasa Polytechnic Dept. of Economics, Ukraine.

Siebert, H. (2006). Locational competition: a neglected paradigm in the international division of labor. The World Economy, 29(2): 137-159.

Swales, K. (1997). A Cost - Benefit Approach to the Evaluation of Regional Selective Assistance", Fiscal Studies, 18(1): $73-85$. 